The myelocytosis I consider comprises the leucocytosis which is present in suppurations and certain other conditions and that which is present in myelogenous leukaemia, the difference being one of degree only and not specific.

If we accept the teaching of Ehrlich that the Iymphocytes are derived from the lymphatic tissues and the other leucocytes from the marrow, one must account in some way for their presence in the blood stream. This is not difficult. For the lymphocyte easy access is obtainable from the lymphatic tissues through the large lymphatic ducts; the myelocytic cells may easily pass from the marrow to the blood in a degree proportionate to their power of amoeboid movement. We can thus understand the presence in the blood of the polymorphonuclear cell and the transitional forms preceding it. Only when the production becomes excessive do we find the large myelo. cyte in the blood. I have recently recognized the ancestral myeloplax in the blood in a case of myelogenous leukaemia. The influence of the $x$ rays in altering the proportion of cells may act in inhibiting excessive production, so that the first cells in leukaemia to diminish in numbers ought to be the large myelocytes, fine or coarse. Next in order of disappearance should be the transitional cell, and last of all the polymorphonuclear.

In examining stained specimens from cases which have not been exposed to the $x$ rays the large myelocytes have been present in great numbers-relatively plus. In stained specimens from a case after exposure to the $x$ rays the polymorphonuclear cells appeared to be the most numerous; then the transitional; and least numerous of all the great myelocytes, fine and coarse. This condition is quite evident without a differential count. Further, in all the cases where the myelaemia has been marked, nucleated red blood corpuscles-normoblasts-have been present and easily detected in stained specimens. After $r$-ray treatment I have failed to discover any nucleated red cells-a point in favour of the idea that the rays act by inhibiting production. Seeing, then, that the $x$ rays exercise a profound influence on the leucocyte production, the questions arise, have they any direct influence upon the cells themselves? Do they alter their morphological characters? To give an unassailable answer to these either in the affirmative or negative, could only be done after a prolonged research with a large series of cases, and ex hausting all the most approved technical methods of fixation and staining. One must also recognize the ever present difficulty of interpreting and determining the true and exact morphology of delicate cell structures. Fixative reagents of various kinds and composition may act differently. For all practical purposes dry heat at $120^{\circ} \mathrm{C}$. for twenty minutes when carefully carried out proves a most useful method, and one which in my hands has provided excellent results in film preparations. In cases which have not been exposed to the $x$ rays I found no difficulty in making good films, equally good in gross and minute structure when stained in a variety of ways.

I am indebted to Sir James Barr for the opportunity of examining the blood from patients under his charge in the Royal Infirmary, and who had been subjected to $x$-ray treatment. Films were made with all care and delicacy, and fixed carefully by the aid of dry heat at $120^{\circ} \mathrm{C}$. for twenty minutes. On proceeding to stain and examine them, however, I found that they had not spread well, nor were the cells so sensitive to the stains used. I second batch was but a repetition of the first. Specimens stained with eosin, dried, and counterstained with methylene blue revealed a diffuse staining of the nuclei as compared to the sharp chromatin stain which is normally seen. To Ehrlich's acid haematoxylin and eosin the nuclei did not respond as they ought, and even with prolonged immersion they stained but feebly. The use of methylene blue revealed a lack of chromatin and basophile reaction, in many cells to a very marked extent.

The eosinophile reaction of the coarsely-granular myelocytes was in many cells diffluent rather than sharp and refractile. In specimens stained with Jenner's stain the same condition was present, but the eosinophile diffluence was less marked. Many of the large myelocytes and transitional cells appeared altered and paler than usual, others diffluent and broken up, not having the sharp spherical outline one ought to expect in a normal cell. Similar changes were observed by the use of Heidenhain's haematoxylin.
The small basophile cells had suffered in an extreme degree; the polymorphonuclear leucocytes less so, and this might be expected, as of all leucocytes they are the most resislant to any form of disintegration. In these, however the same pallor and diffluence of the nucleus was evident.

There was a general tendency for many cells of any variety to take on a diffuse stain in which the nuclei were indistinguishable from the surrounding cytoplasm. Fragmentation of nuclei was not uncommon, especially in the basophile cells.

The so-called "spread cells" which are always to be found in leukaemic blood I found present in much Jarger numbers than usual, indicating an increased vulnerability to technique.

At an autopsy on a man who had died from a relapse of leukaemia, and who had been treated by the $x$ rays, I was enabled to obtain specimens of marrow. On comparing them with films made from the marrow of a case not so treated I found that the coarse eosinophile cells were abundant in the latter, while they were scarce in the former. In the untreated marrow the cells were well formed and the nuclear chromatin responded sharply to the stains used, but after exposure to the $x$ rays many cells were diffluent and stained diffusely without a sharp chromatin reticulum-a condition similar to that recorded in the blood films.

In conclusion, I am of opinion that there is evidence to show that the action of the $x$ rays in leukaemia is of a two-fold character, (1) by inhibiting over-production in the marrow, and (2) by a destructive influence over the leucocytes themselves. The effect is especially noticeable in the cell structures which respond normally to basic dyes, less so in those which respond to acid dyes.

Further evidence is affurded by the fact that the myelocytosis recurs rapidly when the $x$-ray treatment is discontinued.

\section{A CASE OF LIPOMA OF THE PERICARDIUM} BY M. VAUGHAN MCKECHNIE, L.R.C.P., L.R.C.S.ED., EAS\BOURNE.

The patient in this case, a tailor by trade, aged 56 , was first seen by me on March 23rd, 1906. His family history was good but his personal history bad, since he was a confirmed alcoholic. He was very anaemic in appearance, but stated that until two weeks before he had been perfectly well, and that all he complained of was shortness of breath.

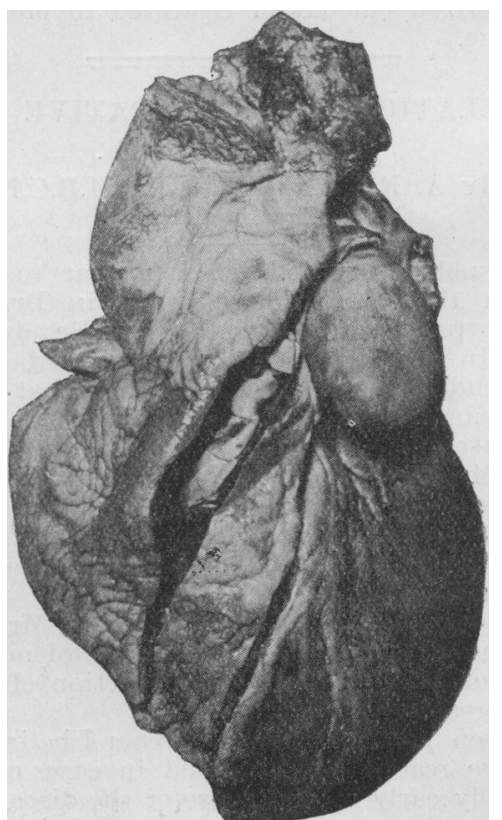

If art with large lipoma lying over left auricular appenclage: right ventricle held open to show thrombus.

State on Examination.-He was a fairly well-nourished man. Heart sounds normal, but upon percussion over the area corresponding to the ascending and transverse part of the arch corresponding to the ascending and transverse part of the arch of the aorta I noticed marked dullness. He had no signs of
aortic aneurysm. Pulse regular in force and frequency. Lungs normal. Liver much enlarged. Urine normal. 
Progress.-On April 11th, 1906, that is, seventeen days after I first saw him, I was sent for and found him in bed suffering from delirium tremens. I was unable to examine him owing to his condition. I called the following morning, April 12th to his condition. I called the following morning, April 12th,
but found he had gone out. The next night, April 13th, I was but found he had gone out. The next night, April 13th,
sent for to see him in a great hurry and found him dead.

Post-mortem Examination. - I duly notified the case to the coroner, Dr. Vere Benson, who ordered a post-mortem examination, of which the following are the notes: Brain normal. Thorax, left lung, pleuro-pneumonia ; right lung much congested. Liver greatly enlarged. Heart weighed $19 \mathrm{oz}$. instead of $11 \mathrm{oz}$., the average weight of a male heart, and was very of 11 oz., the average weight of a male heart, and was very thickly covered with fat. Upon opening the pericardial sac, I pericardial sac below the pulmonary artery.

Pathologist's Report. - This case seemed to me so unique that I took the specimen to Dr. H. S. Gabbett, Pathologist, Eastbourne, for his report, which was as follows:

Lipoma of Pericardium.-The specimen received consists of the heart, pulmonary artery, part of aortic arch, bifurcation of trachea, and adjoining parts. Projecting into the pericardial cavity on the left side is an oval pendulous mass of adipose tissue measuring $2 \frac{3}{4}$ in. in length and $1 \frac{1}{2}$ in. in thickness. It springs from a base situated in the recess of the pericardial sac beneath the left division of the pulmonary artery, and lies upon the left auricular appendage. General excess of subpericardial fat. The left ventricle is dilated, mitral valve somewhat thickened. There is a very dense adberent clot in the right auricle extending from the appendage to the tricuspid orifice, which it partially occupies, and a similar clot in the right ventricle extending up to the pulmonary valves. in the right ventricle extending up to the pulmonary valves.
Tricuspid valve much thickened and distorted. The portion of aortic arch included in the specimen is dilated, and the intima is rough; valves competent.

Remarks.-The photograph, a very good one, shows the large lipoma lying over the left auricular appendix. Dr. H. S. Gabbett showed the specimen at a meeting of the Eastbourne Medical Society, and it was stated that no member had seen a similar specimen or heard of such a case. It is interesting, I take it, from the fact of its being so unique. The specimen has been forwarded to Dr. Byrom Bramwell of Edinburgh, my late teacher.

My best thanks are due to Dr. Gabbett for his report and photograph, and to Mr. J. N. d'Esterre for his assistance at the necropsy, and in helping me to prepare the notes of this case.

\section{A CASE IN WHICH LARGE QUANTITIES OF DIPTEROUS LARVAE WERE PASSED PER ANUM.}

By C. H. CATTLE, M.D., M.R.C.P., HON. PHYSICIAN, NOTTINGHAM GENERAL HOSPITAL.

IN September, 1905, a young man of healthy aspect, aged 19 , came to me, stating that he had a "nest of insects" in his inside, of which he had passed per anum a basinful at one time. For some weeks previously he had not been feeling well. He now complained of abdominal discomfort, but his symptoms were chiefly the result of alarm at the discovery of living grubs in the faeces. He had many fantastic ideas about the insects, such as "they

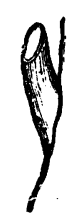

a.

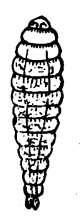

$b$.

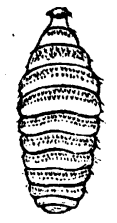

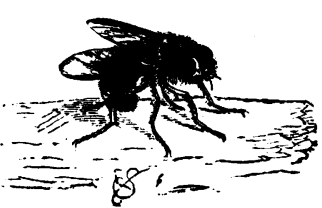

d.
Fig. 1.-Horse botfly (Oestrus equi). a. Egg on a hair, strongly magnified ; $b$, younger larva, magnified : $c$, older larva, magnified

were living on his food and taking his strength," "that he felt them crawling about." From what I have since been able to learn, 1 have no doubt whatever that the parasites were capable of causing considerable irritation, which probably accounted for his lively imagination respecting their behaviour. He had no vomiting or other gastric or intestinal symptoms. I expressed a wish to see some of the insects, and he brought from twenty to thirty

We are indebted to Messrs. Methuen for permission to reproduce slender, flattened, fusiform larvae, about $5 \mathrm{~mm}$. in length. similar to (b), Fig. 1. Two months later he brought four specimens, somewhat.longer and much broader than - the first, and evisurface.

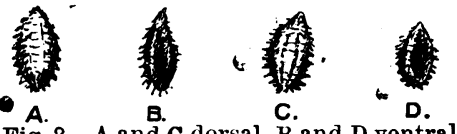

Fig. 2. $-\mathbf{A}$ and $\mathbf{C}$ dorsal, dently of a later stage of development. These are illustrated, drawn

the exact size, in Fig. 2.

I showed the four specimens illustrated in Fig. 2 to Professor Carr, of the Nottingham University College, and he had no difficulty in identifying them as a species of the family Oestridae, or "botflies." The best-known species are the Hypoderma bovis, which infests the subcutaneous tissue of cattle; Oestrus equi, infesting the gastro-intestinal tract of horses; and Oestrus ovis, inhabiting the frontal sinuses of the sheep. The larval forms of these insects are parasitic in the bodies of the animals named, attaching themselves to the tissues by means of hooklets. When about to become pupae, they are voided with the faeces, or escape with secretions, such as pus, their remaining stages being passed in the open air. The female fly lays her eggs in such position as to secure the easy passage of the larvae to the tissues of the host. For instance, the botfly of the horse deposits her eggs on the hair of the shoulder or knee, whence they are licked off and conveyed to the stomach.

The man who is the subject of this paper, although living in the country, was not a farm labourer, or immediately concerned in tending domestic animals. It remains, therefore, quite uncertain how he became infected. His evacuations have been regularly watched and he now (March, 1906) very rarely sees any larvae, and not more than one or two at once. The parasiticides used were various purgatives : santonine, turpentine, and calomel in 5.gr. doses; these, however, did not seem to have much effect.

There is very little information on this subject in medical textbooks. Osler quotes from Finlayson the case of a physician who passed per anum a large quantity of the larvae of the flower-fly (Anthomyia canicularis). The same authority says that botflies occasionally attack the skin of man, rarely, however, in temperate climates; but does not mention their presence in the human intestine. Larvae of the Musca domestica have been occasionally vomited or passed in the faeces, and those of the bluebottle and flesh-fly have been found in neglected wounds.

An Antivivisectionist Sermon.-A correspondent has forwarded us a cutting from the Record which contains an abstract of a sermon preached at Christ Church, Endell Street, on June 26th. The occasion was the annual service of the Church Antivivisection League, and what the preacher, the Rev. L. S. Lewis, Curate of All Saints, Mile End, had to say upon the subject was thoroughly in keeping. A statement had been made in the morning papers of that day to the effect that 5,000 more experiments on living animals were performed in 1905 than in the previous year. This circumstance Mr. Lewis took for his text, and it is perhaps fortunate that he did so, since, possibly, if he had given himself more time to study the matter, what he would have to say might have been less pleasing to antivivisectors, and more in accordance with common sense. As it was, his address, with one exception, was painfully lacking in originality. As usual, antivivisectors were actuated by the meanest motives : love of money, or love of fame. Possibly there might be some who were desirous of serving their fellowcreatures, but even if there were they were acting from want of principle. The general dreariness and banality, in short, seems to have been only relieved by his con. cluding statement of a belief that animals not less than man are included in the scope of the Redemption. It is a doctrine which may be commended to the study of theologists; when they have settled it, possibly those who share Mr. Lewis's prejudices might observe with some advantage the general scheme of Nature, note the general preying of animal upon animal, of insect upon insect, and ask themselves whether, apart from physical sufferings; th e standpoint of nearly all Christian sects is not that we are all here in pursuance of a vast experiment,' being sent into the world with free wills, and inoculated at binth with the toxins of good and evil. Unfortunately however, there are no controls, and the result can never be known to any of us in mundane life. 